\title{
Aspromonas composti gen. nov., sp. nov., a novel member of the family Xanthomonadaceae
}

\author{
Long Jin, Kwang Kyu Kim, Wan-Taek Im, Hee-Chan Yang \\ and Sung-Taik Lee \\ Department of Biological Sciences, Korea Advanced Institute of Science and Technology,
373-1 Guseong-dong, Yuseong-gu, Daejeon 305-701, Republic of Korea
}

Correspondence

Sung-Taik Lee

e_stlee@kaist.ac.kr
Two novel bacteria, strains TR7- $09^{\top}$ and P2-12-1, were isolated from samples of compost and river sediment, respectively. The strains comprised Gram-negative, motile, non-spore-forming rods, produced creamy white colonies on R2A agar, contained $\mathrm{Q}-8$ as the predominant

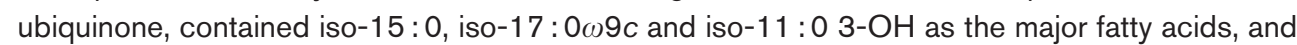
had polar lipid profiles consisting of phosphatidylmethylethanolamine, phosphatidylethanolamine, phosphatidylglycerol and an unknown phospholipid. Phylogenetic analysis based on 16S rRNA gene sequences showed that the strains were most closely related to Thermomonas haemolytica DSM $13605^{\top}$, Silanimonas lenta KCTC $12236^{\top}$ and Xanthomonas campestris LMG $568^{\top}$ (with 92.5, 92.0 and $92.0 \%$ sequence similarity, respectively) and formed a separate lineage within the family Xanthomonadaceae. The combined genotypic and phenotypic data supported the conclusion that the strains represent a novel genus and species, for which the name Aspromonas composti gen. nov., sp. nov. is proposed. The type strain is TR7-09 ${ }^{\top}(=\mathrm{KCTC}$ $12666^{\top}=$ DSM $18010^{\top}$ ).
The family Xanthomonadaceae, which belongs to the class Gammaproteobacteria, was described recently (Saddler \& Bradbury, 2005) and contains 18 recognized genera (type genus, Xanthomonas). However, according to Rule 51b(1) of the Bacteriological Code (1990 Revision; Lapage et al., 1992), the name of this family is illegitimate because it contains the genus Lysobacter, which is the type genus for the family Lysobacteraceae. Thirteen genera in the family Xanthomonadaceae (except the genera Lysobacter, Pseudoxanthomonas, Stenotrophomonas, Thermomonas and Xanthomonas) consist of one or two species. The genera including Aquimonas (Saha et al., 2005), Dokdonella (Yoon et al., 2006), Dyella (Xie \& Yokota, 2005), Luteibacter (Johansen et al., 2005) and Silanimonas (Lee et al., 2005) have been described recently. Representative strains belonging to this family have been isolated from a variety of environmental sources including soil, water, biofilm, sludge, plants, fly larvae and human clinical specimens as if they reflected the common habitats of proteobacteria (Saddler \& Bradbury, 2005).

During an investigation of the bacterial community present in compost from a farm in Daejeon, Korea, strain TR7-09 ${ }^{\mathrm{T}}$

The GenBank/EMBL/DDBJ accession number for the $16 \mathrm{~S}$ rRNA gene sequence of strain TR7-09' is AM229324.

A two-dimensional thin-layer chromatogram of polar lipids from strain TR7-09 ${ }^{\top}$ and a table showing the fatty acids of strains TR7-09 ${ }^{\top}$ and P212-1 are available with the online version of this paper. was isolated. Strain P2-12-1 was isolated during the screening of phenol-degrading bacteria from river sediment near the Gumi industrial complex in Korea. A compost sample was collected and diluted serially in $0.85 \%$ saline solution. Aliquots of each serial dilution were spread on R2A agar (Difco) and incubated at $30{ }^{\circ} \mathrm{C}$ for 7 days. A creamy white colony, designated strain $\mathrm{TR} 7-09^{\mathrm{T}}$, was isolated. A sediment sample from Nakdong River was initially stimulated with 100 p.p.m. (1.06 mM) phenol and then the stimulated culture was diluted serially in $0.85 \%$ saline solution. Aliquots of each serial dilution were spread on R2A agar and incubated at $25{ }^{\circ} \mathrm{C}$ for 7 days. A creamy white colony, designated P2-12-1, was isolated. Both of the two isolates were subcultured on $\mathrm{R} 2 \mathrm{~A}$ agar at $30{ }^{\circ} \mathrm{C}$ for $48 \mathrm{~h}$. On the basis of 16S rRNA gene sequence comparisons, the two strains were shown to belong to the family Xanthomonadaceae of the Gammaproteobacteria, but they showed low levels of 16S rRNA gene sequence similarity with respect to representative species of the genera within this family. For further classification, these strains were subjected to a polyphasic investigation.

For most experiments, strains were cultivated on R2A agar or broth (Difco) at $30{ }^{\circ} \mathrm{C}$ for $48 \mathrm{~h}$. For the analysis of fatty acids, strains were cultivated on tryptic soy agar (BBL) at $30{ }^{\circ} \mathrm{C}$ for $48 \mathrm{~h}$. Thermomonas haemolytica DSM $13605^{\mathrm{T}}$, Silanimonas lenta KCTC $12236^{\mathrm{T}}$ and Xanthomonas campestris DSM $3586^{\mathrm{T}}$ were used as reference strains under the same conditions. 
The Gram reaction was performed as described by Gerhardt et al. (1994). Cell morphology and motility were observed under a phase-contrast microscope (Optiphot; Nikon), at $\times 1000$ magnification, using cells grown on R2A agar for 1-7 days. The presence of flagella was determined by using transmission electron microscopy (JEM-1011; JEOL) after negative staining of the cells with $2 \%(\mathrm{w} / \mathrm{v})$ uranyl acetate. Oxidase activity was tested using $1 \%$ tetramethyl-p-phenylenediamine (Tarrand \& Groschel, 1982 ) and catalase activity was tested using $3 \% \mathrm{H}_{2} \mathrm{O}_{2}$. Growth was investigated on R2A agar at different temperatures $\left(5,10,15,20,25,30,37,42\right.$ and $\left.45{ }^{\circ} \mathrm{C}\right)$, at different $\mathrm{NaCl}$ concentrations $(1,2,3$ and $5 \%)$ and at pH 5-10 (using increments of $1 \mathrm{pH}$ unit). For the $\mathrm{pH}$ experiments, the appropriate biological buffers were used, as follows: $\mathrm{Na}_{2} \mathrm{HPO}_{4} / \mathrm{NaH}_{2} \mathrm{PO}_{4}$ buffer was used for $\mathrm{pH} 5$ 7, and $\mathrm{Na}_{2} \mathrm{CO}_{3} / \mathrm{NaHCO}_{3}$ buffer was used for $\mathrm{pH} 8-10$ (Bates \& Bower, 1956; Gomori, 1955). Growth on nutrient agar (Difco) was investigated. Degradation of DNA was investigated, using DNA agar (Difco) supplemented with $0.01 \%$ toluidine blue (Merck). Degradation of casein, chitin and starch (Atlas, 1993), degradation of lipid (Kouker \& Jaeger, 1987) and degradation of cellulose and xylan (Ten et al., 2004) were also investigated. Duplicate antibiotic-susceptibility tests were performed using filterpaper discs containing the following: ampicillin $(10 \mu \mathrm{g})$, erythromycin $(30 \mu \mathrm{g})$, kanamycin $(30 \mu \mathrm{g})$, neomycin $(30 \mu \mathrm{g})$, penicillin $\mathrm{G}(10 \mathrm{IU})$ and streptomycin $(10 \mu \mathrm{g})$ (Sigma). Tests of carbon-source utilization, tests for acid production and tests for additional physiological features were performed using API 20NE, API 50CH and API ZYM galleries according to the instructions of the manufacturer (bioMérieux).

Fatty acid methyl esters were prepared and analysed as described previously (Klatte et al., 1994) using the standard Microbial Identification System (MIDI) for automated gas chromatographic analysis (Sasser, 1990; Kämpfer \& Kroppenstedt, 1996). Isoprenoid quinones were extracted and purified as described previously (Tindall, 1990), dried preparations were dissolved in $200 \mu \mathrm{l}$ 2-propanol and 1$10 \mu \mathrm{l}$ samples were separated by using HPLC without further purification. Polar lipids were extracted, examined by two-dimensional TLC and identified using published procedures (Minnikin et al., 1977).

Extraction of genomic DNA, PCR-mediated amplification of the 16S rRNA genes and sequencing of purified PCR products were carried out according to Rainey et al. (1996). The 16S rRNA gene sequences were aligned with published sequences, retrieved from EMBL, using CLUSTAL_X (Thompson et al., 1997) and edited by using BioEdit (Hall, 1999). The phylogenetic tree was constructed on the basis of the neighbour-joining method (Saitou \& Nei, 1987); distances were estimated by using the method of Jukes \& Cantor (1969) with MEGA, version 2.1 (Kumar et al., 2001). The resultant neighbour-joining tree topology was evaluated by bootstrap analysis (Felsenstein, 1985) based on 1000 resampled datasets. DNA $\mathrm{G}+\mathrm{C}$ contents were determined by using HPLC after hydrolysis, as described by Tamaoka \& Komagata (1984), and non-methylated $\lambda$ DNA (Sigma) was used as a standard. To determine genomic relatedness, DNA-DNA hybridization was performed fluorometrically by the method of Ezaki et al. (1989) using DNA probes labelled with photobiotin (A1935; Sigma) and microdilution wells (96-well microplate; Greiner Bio-one).

Strains TR7-09 ${ }^{\mathrm{T}}$ and P2-12-1 formed visible colonies (about 1-2 $\mathrm{mm}$ in diameter) within $48 \mathrm{~h}$ on R2A agar incubated at $30{ }^{\circ} \mathrm{C}$. Growth occurred at temperatures ranging from 20 to $42{ }^{\circ} \mathrm{C}$, but no growth was observed at $45{ }^{\circ} \mathrm{C}$ or at temperatures below $15{ }^{\circ} \mathrm{C}$. Growth occurred at pH 6-9, but no growth was observed at pH 5 or 10 . The colonies were creamy white, translucent, convex and circular with entire edges. The cells were Gram-negative, catalase-negative, oxidase-positive, motile rods with single polar flagellum. Detailed physiological and biochemical characteristics are summarized in Table 1 and in the species description.

The only respiratory quinone present was ubiquinone Q-8. The fatty acids iso- $15: 0$, iso- $17: 0 \omega 9 c$ and iso-11:0 3-OH were predominant. The complete fatty acid profiles of strains TR7-09 ${ }^{\mathrm{T}}$ and $\mathrm{P} 2-12-1$ are presented in Supplementary Table S1 (available in IJSEM Online). The polar lipids comprised phosphatidylmethylethanolamine, phosphatidylethanolamine, phosphatidylglycerol and an unknown phospholipid; a two-dimensional thin-layer chromatogram of the polar lipids from strain TR7 $-09^{\mathrm{T}}$ is shown in Supplementary Fig. S1, available in IJSEM Online.

The almost-complete 16S rRNA gene sequences (approx. $1500 \mathrm{nt}$ ) of strains TR7-09 ${ }^{\mathrm{T}}$ and P2-12-1 were determined and compared with those of representative species within the family Xanthomonadaceae. Strains TR7-09 ${ }^{\mathrm{T}}$ and P2-121, which shared $99.9 \%$ sequence similarity, showed the highest levels of sequence similarity with $T$. haemolytica DSM $13605^{\mathrm{T}}$, S. lenta KCTC $12236^{\mathrm{T}}$ and X. campestris LMG $568^{\mathrm{T}}$, with values of $92.5,92.0$ and $92.0 \%$, respectively, which are below the threshold level that is generally used to define a novel genus (Ludwig et al., 1998). The levels of sequence similarity with respect to other representative species within the family Xanthomonadaceae were in the range $83.2-91.5 \%$. In the phylogenetic tree (Fig. 1), strains TR7- $09^{\mathrm{T}}$ and P2-12-1 formed a separate lineage within the family Xanthomonadaceae. The DNADNA hybridization level between strains TR7- $09^{\mathrm{T}}$ and P212-1 was $92 \%$, which confirmed that they belonged to the same genomic species (Wayne et al., 1987).

In addition, strains TR7- $09^{\mathrm{T}}$ and $\mathrm{P} 2-12-1$ showed several significant phenotypic differences with respect to their closest phylogenetic neighbours, i.e. T. haemolytica, S. lenta and $X$. campestris (Table 1). The strains were mesophilic, whereas T. haemolytica and S. lenta were slightly thermophilic. The strains did not show catalase activity, whereas $T$. haemolytica and $S$. lenta did. When fatty acid 
Table 1. Phenotypic characteristics differentiating Aspromonas composti from representatives of related genera

Species: 1, A. composti; 2, T. haemolytica; 3, S. lenta; 4, X. campestris. Data for A. composti were generated in this study; all other data were taken from previous studies (Bradbury, 1984; Busse et al., 2002; Finkmann et al., 2000; Lee et al., 2005; Vauterin et al., 1995, 1996). All taxa showed oxidase activity and polar flagellation and all had ubiquinone Q-8 as the major quinone. +, Positive; -, negative.

\begin{tabular}{|c|c|c|c|c|}
\hline Characteristic & 1 & 2 & 3 & 4 \\
\hline Temperature optimum $\left({ }^{\circ} \mathrm{C}\right)$ & 30 & $37-50$ & 47 & $25-30$ \\
\hline Catalase & - & + & + & - \\
\hline Urease & + & + & - & - \\
\hline Major fatty acids ${ }^{*}$ & iso- $15: 0$, iso- $17: 1$ & iso- $15: 0$, iso- $16: 0$ & iso- $15: 0$, iso- $16: 0$ & $\begin{array}{c}\text { iso- } 15: 0 \text {, anteiso- } 15: 0 \\
16: 1\end{array}$ \\
\hline Major hydroxyl fatty acid* & iso-11:0 $3-\mathrm{OH}$ & iso- $11: 03-\mathrm{OH}$ & iso-11:0 $3-\mathrm{OH}$ & iso-13:0 $3-\mathrm{OH}$ \\
\hline Major polar lipid(s) $\dagger$ & PG, PE, PME & DPG, PE, PG & DPG, PE, PG, PL & DPG, PE, PG, PME, PL \\
\hline DNA G $+C$ content $(\mathrm{mol} \%)$ & $70.8-71.1$ & $67.1-68.7$ & 50.7 & $65.8-66.6$ \\
\hline
\end{tabular}

${ }^{\star}$ Fatty acid composition was analysed with cells grown at the optimal temperature.

$\nmid$ DPG, Diphosphatidylglycerol; PE, phosphatidylethanolamine; PG, phosphatidylglycerol; PL, unknown phospholipid; PME, phosphatidylmethylethanolamine.

compositions were analysed using cells grown at optimal temperatures, the strains had fatty acid profiles that differed from those of T. haemolytica, S. lenta and X. campestris, i.e. TR7-09 ${ }^{\mathrm{T}}$ and P2-12-1 contained iso-17: 1 as one of the major fatty acids. Although the fatty acid compositions were analysed using cells grown at the temperature of $30{ }^{\circ} \mathrm{C}$, the isolates showed profiles that differed from those of their phylogenetic neighbours, e.g. strains TR7-09 ${ }^{\mathrm{T}}$ and P2-12-1 lacked 14:0 and 15:1 iso F (see Supplementary Table S1). The strains showed different polar lipid profiles, i.e. the absence of diphosphatidylglycerol, with respect to those of T. haemolytica, S. lenta and X. campestris. The DNA $G+C$ contents of the strains were much higher than that of S. lenta, but the range was similar to those of $T$. haemolytica and $X$. campestris.

On the basis of the 16S rRNA gene dissimilarity with respect to related taxa, together with the phylogenetically distinct position, unique phenotypic characteristics and genomic relatedness, strains TR7- $09^{\mathrm{T}}$ and $\mathrm{P} 2-12-1$ represent a novel genus and species, for which the name Aspromonas composti gen. nov., sp. nov. is proposed.

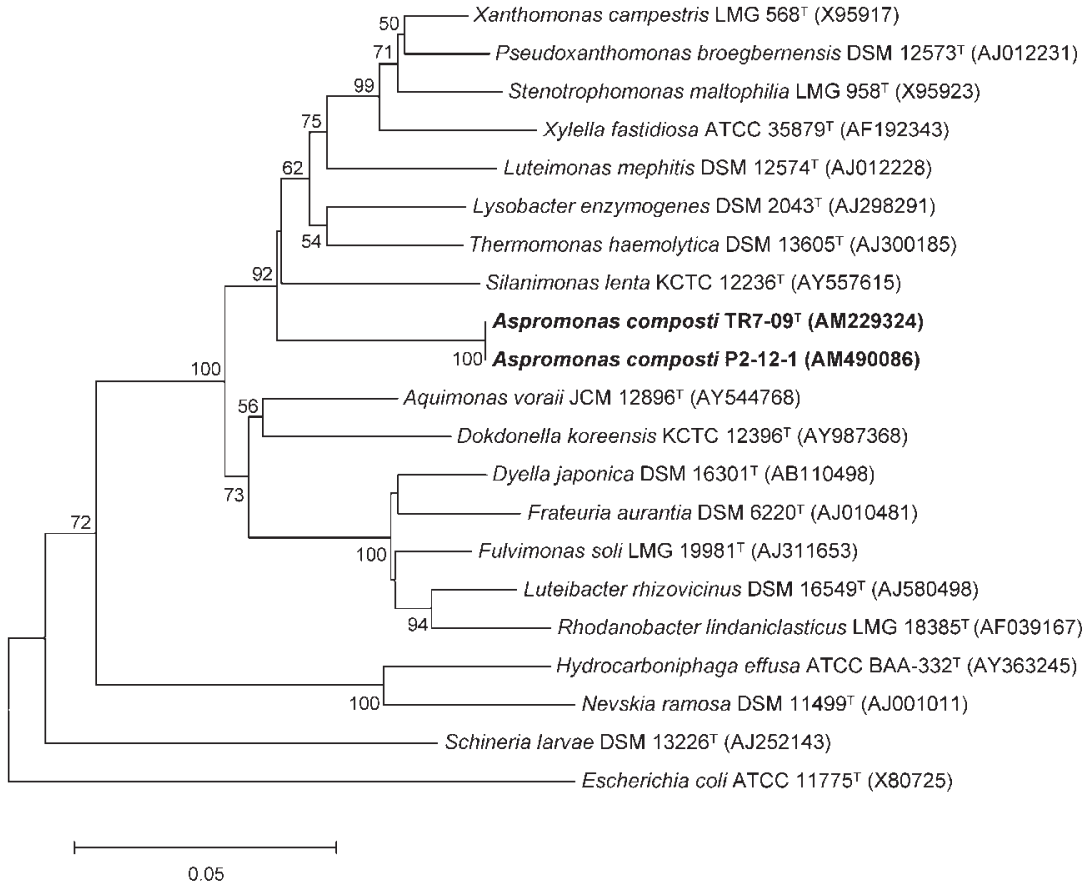

Fig. 1. Neighbour-joining phylogenetic tree, based on 16S rRNA gene sequences, showing the positions of strains TR7-09 ${ }^{\top}$ and P2-12-1 among representative species within the family Xanthomonadaceae. Numbers at branching points refer to bootstrap percentages (from 1000 resamplings; only values above $50 \%$ are shown). Bar, 5 substitutions per 100 nucleotide positions. 


\section{Description of Aspromonas gen. nov.}

Aspromonas (As.pro.mo'nas. Gr. adj. aspros white; L. fem. n. monas a unit, monad; N.L. fem. n. Aspromonas a white monad).

Cells are Gram-negative, non-spore-forming, motile rods with single polar flagellum. Cells are mesophilic and neutrophilic. Cells are oxidase-positive but catalasenegative. The major fatty acids are iso- $15: 0$, iso- $17: 0 \omega 9 c$ and iso-11:0 3-OH. The polar lipids comprise phosphatidylmethylethanolamine, phosphatidylethanolamine, phosphatidylglycerol and an unknown phospholipid. The predominant respiratory quinone is ubiquinone Q-8. The type species is Aspromonas composti.

\section{Description of Aspromonas composti sp. nov.}

Aspromonas composti (com.pos'ti. N.L. n. compostum - $i$ compost; N.L. gen. n. composti of compost).

Cells are Gram-negative, non-spore-forming, motile rods $(0.4-0.5 \times 1.0-1.8 \mu \mathrm{m})$ with single polar flagellum. Good growth is observed on R2A agar, tryptic soy agar and nutrient agar. Growth occurs at $20-42{ }^{\circ} \mathrm{C}$ (optimum, $30{ }^{\circ} \mathrm{C}$ ) and at $\mathrm{pH}$ 6-9 (optimum, $\mathrm{pH}$ 7). Growth occurs in the presence of 1 and $2 \% \mathrm{NaCl}$, but not above $3 \%$. Colonies are creamy white, translucent, convex and circular with entire edges and produce a diffusible brownish decolorization of the medium after prolonged incubation (5-7 days). Oxidase-positive but catalase-negative. Indole is not produced. Arginine dihydrolase and urease are produced but $\beta$-galactosidase is not produced. Nitrate and nitrite are not reduced. Casein and DNA are hydrolysed, but aesculin, cellulose, chitin, gelatin, lipid, starch and xylan are not hydrolysed. According to the results from the API ZYM tests, 2-naphthyl phosphate ( $\mathrm{pH} 8.5)$, 2-naphthyl butyrate, 2-naphthyl caprylate, L-leucyl 2-naphthylamide, 2-naphthyl phosphate (pH 5.4), N-glutaryl-phenylalanine 2-naphthylamide and naphthol-AS-BI-phosphate are hydrolysed, but 2-naphthyl myristate, L-valyl 2-naphthylamide, L-cystyl 2-naphthylamide, $\mathrm{N}$-benzoyl-DL-arginine 2-naphthylamide, 6-bromo-2-naphthyl $\alpha$-D-galactopyranoside, 2-naphthyl $\beta$-D-galactopyranoside, naphthol-AS$\mathrm{BI}-\beta$-D-glucuronide, 2 -naphthyl $\alpha$-D-glucopyranoside, 6-bromo-2-naphthyl $\quad \beta$-D-glucopyranoside, $\quad 1$-naphthyl $N$-acetyl- $\beta$-D-glucosaminide, 6 -bromo-2-naphthyl $\alpha$-Dmannopyranoside and 2-naphthyl $\alpha$-L-fucopyranoside are not hydrolysed. Acid is produced from 5-ketogluconate, but not from glycerol, erythritol, D-arabinose, L-arabinose, ribose, D-xylose, L-xylose, adonitol, methyl $\beta$-D-xylose, galactose, glucose, fructose, mannose, sorbose, rhamnose, dulcitol, inositol, mannitol, sorbitol, methyl $\alpha$-D-mannoside, methyl $\alpha$-D-glucoside, $N$-acetylglucosamine, amygdalin, arbutin, aesculin, salicin, cellobiose, maltose, lactose, melibiose, sucrose, trehalose, inulin, melezitose, raffinose, starch, glycogen, xylitol, gentiobiose, D-turanose, D-lyxose, D-tagatose, D-fucose, L-fucose, D-arabitol, L-arabitol, gluconate or 2-ketogluconate. The following compounds are utilized as sole carbon sources: glycogen, rhamnose, acetate, malonate, suberate, 3-hydroxybenzoate and L-serine. The following carbon sources are not utilized: D-glucose, $\mathrm{N}$ acetylglucosamine, maltose, D-ribose, L-arabinose, mannose, adipate, gluconate, caprate, malate, valerate, mannitol, citrate, phenyl acetate, inositol, sucrose, itaconate, DL-lactate, L-alanine, 5-ketogluconate, salicin, D-melibiose, L-fucose, D-sorbitol, propionate, histidine, 2-ketogluconate, 3-hydroxybutyrate, 4-hydroxybenzoate and L-proline. Susceptible to kanamycin and neomycin. Resistant to ampicillin, erythromycin, penicillin $G$ and streptomycin. The major respiratory quinone is ubiquinone Q-8. The predominant fatty acids are iso- $15: 0$, iso- $17: 0 \omega 9 \mathrm{c}$ and iso11:0 3-OH. The polar lipids comprise phosphatidylmethylethanolamine, phosphatidylethanolamine, phosphatidylglycerol and an unknown phospholipid. The $\mathrm{G}+\mathrm{C}$ content of the DNA is $70.8-71.1 \mathrm{~mol} \%$ ( $70.8 \mathrm{~mol} \%$ for the type strain).

The type strain, TR7 $-09^{\mathrm{T}}\left(=\right.$ KCTC $\left.12666^{\mathrm{T}}=\mathrm{DSM} 18010^{\mathrm{T}}\right)$, was isolated from compost.

\section{Acknowledgements}

This work was supported by Eco-Technopia-21, Ministry of Environment, Republic of Korea.

\section{References}

Atlas, R. M. (1993). Handbook of Microbiological Media. Edited by L. C. Parks. Boca Raton, FL: CRC Press.

Bates, R. G. \& Bower, V. E. (1956). Alkaline solutions for $\mathrm{pH}$ control. Anal Chem 28, 1322-1324.

Bradbury, J. F. (1984). Genus II. Xanthomonas Dowson 1939, $187^{\mathrm{AL}}$. In Bergey's Manual of Systematic Bacteriology, vol. 1, pp. 199-210. Edited by N. R. Krieg \& J. G. Holt. Baltimore: Williams \& Wilkins.

Busse, H.-J., Kämpfer, P., Moore, E. R. B., Nuutinen, J., Tsitko, I. V., Denner, E. B., Vauterin, L., Valens, M., Rosselló-Mora, R. \& Salkinoja-Salonen, M. S. (2002). Thermomonas haemolytica gen. nov., sp. nov., a $\gamma$-proteobacterium from kaolin slurry. Int J Syst Evol Microbiol 52, 473-483.

Ezaki, T., Hashimoto, Y. \& Yabuuchi, E. (1989). Fluorometric deoxyribonucleic acid-deoxyribonucleic acid hybridization in microdilution wells as an alternative to membrane filter hybridization in which radioisotopes are used to determine genetic relatedness among bacterial strains. Int J Syst Bacteriol 39, 224-229.

Felsenstein, J. (1985). Confidence limits on phylogenies: an approach using the bootstrap. Evolution 39, 783-791.

Finkmann, W., Altendorf, K., Stackebrandt, E. \& Lipski, A. (2000). Characterization of $\mathrm{N}_{2} \mathrm{O}$-producing Xanthomonas-like isolates from biofilters as Stenotrophomonas nitritireducens sp. nov., Luteimonas mephitis gen. nov., sp. nov. and Pseudoxanthomonas broegbernensis gen. nov., sp. nov. Int J Syst Evol Microbiol 50, 273-282.

Gerhardt, P., Murray, R. G. E., Wood, W. A. \& Krieg, N. R. (editors) (1994). Methods for General and Molecular Bacteriology. Washington, DC: American Society for Microbiology.

Gomori, G. (1955). Preparation of buffers for use in enzyme studies. Methods Enzymol 1, 138-146.

Hall, T. A. (1999). BioEdit: a user-friendly biological sequence alignment editor and analysis program for Windows 95/98/NT. Nucleic Acids Symp Ser 41, 95-98. 
Johansen, J. E., Binnerup, S. J., Kroer, N. \& Mølbak, L. (2005). Luteibacter rhizovicinus gen. nov., sp. nov., a yellow-pigmented gammaproteobacterium isolated from the rhizosphere of barley (Hordeum vulgare L.). Int J Syst Evol Microbiol 55, 2285-2291.

Jukes, T. H. \& Cantor, C. R. (1969). Evolution of protein molecules. In Mammalian Protein Metabolism, vol. 3, pp. 21-132. Edited by H. N. Munro. New York: Academic Press.

Kämpfer, P. \& Kroppenstedt, R. M. (1996). Numerical analysis of fatty acid patterns of coryneform bacteria and related taxa. Can J Microbiol 42, 989-1005.

Klatte, S., Rainey, F. A. \& Kroppenstedt, R. M. (1994). Transfer of Rhodococcus aichiensis Tsukamurella 1982 and Nocardia amarae Lechevalier \& Lechevalier 1974 to the genus Gordona as Gordona aichiensis comb. nov. and Gordona amarae comb. nov. Int J Syst Bacteriol 44, 769-773.

Kouker, G. \& Jaeger, K. (1987). Specific and sensitive plate assay for bacterial lipases. Appl Environ Microbiol 53, 211-213.

Kumar, S., Tamura, K., Jakobsen, I. B. \& Nei, M. (2001). MEGA2: molecular evolutionary genetics analysis software. Bioinformatics 17, 1244-1245.

Lapage, S. P., Sneath, P. H. A., Lessel, E. F., Skerman, V. B. D., Seeliger, H. P. R. \& Clark, W. A. (editors) (1992). International Code of Nomenclature of Bacteria (1990 Revision). Bacteriological Code. Washington, DC: American Society for Microbiology.

Lee, E. M., Jeon, C. O., Choi, I., Chang, K.-S. \& Kim, C.-J. (2005), Silanimonas lenta gen. nov., sp. nov., a slightly thermophilic and alkaliphilic gammaproteobacterium isolated from a hot spring. Int $J$ Syst Evol Microbiol 55, 385-389.

Ludwig, W., Strunk, O., Klugbauer, S., Klugbauer, N., Weizenegger, M., Neumaier, J., Bachleitner, M. \& Schleifer, K. H. (1998). Bacterial phylogeny based on comparative sequence analysis. Electrophoresis 19, 554-568.

Minnikin, D. E., Patel, P. V., Alshamaony, L. \& Goodfellow, M. (1977). Polar lipid composition in the classification of Nocardia and related bacteria. Int J Syst Bacteriol 27, 104-117.

Rainey, F. A., Ward-Rainey, N., Kroppenstedt, R. M. \& Stackebrandt, E. (1996). The genus Nocardiopsis represents a phylogenetically coherent taxon and a district actinomycete lineage: proposal of Nocardiopsaceae fam. nov. Int J Syst Bacteriol 46, 1088-1092.

Saddler, G. S. \& Bradbury, J. F. (2005). Family I. Xanthomonadaceae fam. nov. In Bergey's Manual of Systematic Bacteriology, 2nd edn, vol. 2 (The Proteobacteria), part B (The Gammaproteobacteria), p. 63. Edited by D. J. Brenner, N. R. Krieg, J. T. Staley \& G. M. Garrity. New York: Springer.
Saha, P., Krishnamurthi, S., Mayilraj, S., Prasad, G. S., Bora, T. C. \& Chakrabarti, T. (2005). Aquimonas voraii gen. nov., sp. nov., a novel gammaproteobacterium isolated from a warm spring of Assam, India. Int J Syst Evol Microbiol 55, 1491-1495.

Saitou, N. \& Nei, M. (1987). The neighbour-joining method; a new method for reconstructing phylogenetic trees. Mol Biol Evol 4, 406-425.

Sasser, M. (1990). Identification of Bacteria by Gas chromatography of Cellular Fatty Acids, MIDI Technical Note 101. Newark, DE: MIDI Inc.

Tamaoka, J. \& Komagata, K. (1984). Determination of DNA base composition by reversed-phase high-performance liquid chromatography. FEMS Microbiol Lett 25, 125-128.

Tarrand, J. J. \& Groschel, D. H. M. (1982). Rapid, modified oxidase test for oxidase-variable bacterial isolates. J Clin Microbiol 16, $772-774$

Ten, L. N., Im, W.-T., Kim, M.-K., Kang, M. S. \& Lee, S.-T. (2004). Development of a plate technique for screening of polysaccharidedegrading microorganisms by using a mixture of insoluble chromogenic substrates. J Microbiol Methods 56, 375-382.

Thompson, J. D., Gibson, T. J., Plewniak, F., Jeanmougin, F. \& Higgins, D. G. (1997). The CLUSTAL_X windows interface: flexible strategies for multiple sequence alignment aided by quality analysis tools. Nucleic Acids Res 25, 4876-4882.

Tindall, B. J. (1990). A comparative study of the lipid composition of Halobacterium saccarovorum from various sources. Syst Appl Microbiol 13, 128-130.

Vauterin, L., Hoste, B., Kersters, K. \& Swings, J. (1995). Reclassification of Xanthomonas. Int J Syst Bacteriol 45, 472-489.

Vauterin, L., Yang, P. \& Swings, J. (1996). Utilization of fatty acid methyl esters for the differentiation of new Xanthomonas species. Int $J$ Syst Bacteriol 46, 298-304.

Wayne, L. G., Brenner, D. J., Colwell, R. R., Grimont, P. A. D., Kandler, O., Krichevsky, M. I., Moore, L. H., Moore, W. E. C., Murray, R. G. E. \& other authors (1987). International Committee on Systematic Bacteriology. Report of the ad hoc committee on reconciliation of approaches to bacterial systematics. Int J Syst Bacteriol 37, 463-464.

Xie, C.-H. \& Yokota, A. (2005). Dyella japonica gen. nov., sp. nov., a $\gamma$-proteobacterium isolated from soil. Int J Syst Evol Microbiol 55, 753-756.

Yoon, J.-H., Kang, S.-J. \& Oh, T.-K. (2006). Dokdonella koreensis gen. nov., sp. nov., isolated from soil. Int J Syst Evol Microbiol 56, $145-150$. 